\title{
Construção de personagens femininos e universos transmídia - um método para a criação do case "Medusas" na franquia The Rotfather
}

\author{
Isabel Cristina Fontão \\ Universidade Federal de Santa Catarina, Brasil \\ Mônica Stein \\ Universidade Federal de Santa Catarina, Brasil
}

\begin{abstract}
This paper presents the creation of female characters and transmedia universes, adapting the Double Diamond Method from Design Council to create three concepts of female characters for "Medusas" story from The Rotfather Franchise. Based on the narrative and psychological profiles created by G2E [Education and Entertainment Research Group], structures the creative process in the four steps of the method - Discover, Define, Develop, and Deliver - presenting a humanized and feminist female representation that prioritizes nuances of their personalities. Within the creative process, this paper presents the alternatives created until the final visual conception of each character for the story that takes place in 1898.
\end{abstract}

Keywords: Movies, Female Characters, Transmedia Franchise, Double Diamond Method, The Rotfather.

\section{Introdução}

Segundo Jenkins (2003), a sociedade encontram-se atualmente em uma era de convergência midiática que torna inevitável o fluxo de conteúdo através de múltiplos canais de mídias. Nessas circunstâncias, observa-se o ambiente ideal para a implantação e prosperidade de franquias transmídias, classificado por Jenkins (2007) como um processo onde a dispersão sistemática de elementos integrais de ficção gera uma experiência coordenada e unificada de entretenimento, onde cada veículo oferece uma contribuição singular para o desenvolvimento da história. A efetividade dessa abordagem pode ser observada no sucesso de gigantes da indústria como Disney, Marvel Comics e Pokémon, que se mantêm relevantes em seu engajamento com o público através de filmes, histórias em quadrinhos (HQs), animações, brinquedos, video games, etc.

A estrutura da narrativa transmídia permite uma intercambiabilidade de protagonismo, ou seja, dependendo da mídia em que a história está sendo contada, diferentes vivências e perspectivas podem ser exploradas, de forma que um personagem pode ser protagonista em uma instância e secundário em outra, exigindo uma construção coerente e aprofundada de todas as personalidades. (Rosa, 2018).

O presente trabalho usa como pano de fundo o universo transmídia The Rotfather, projeto de pesquisa teórico-prático do G2E (Grupo de Educação e Entretenimento), grupo de pesquisa do Departamento de Expressão Gráfica da Universidade Federal de
Santa Catarina (UFSC), especificamente para a criação de concepts de personagens para a história em quadrinhos em desenvolvimento Medusas, utilizando como base toda a pesquisa narrativa e artística pré-realizada pelos diversos integrantes do projeto.

\section{Metodologia}

Como dito anteriormente, este trabalho faz uso do processo de pré-produção da $\mathrm{HQ}$ em desenvolvimento Medusas, apoiando-se na narrativa juntamente com os perfis psicológicos das personagens e o universo geral da franquia The Rotfather, onde a história está inserida.

Através do método Double Diamond (diamante duplo) cunhado pelo Design Council (2015) foi estabelecida a forma de desenvolvimento prático do projeto. Esse método consiste nos seguintes passos: "Descobrir", que consiste no primeiro quarto do modelo e refere-se ao início do projeto; "Definir", o segundo quarto referente ao estágio de definição e assimilação das possibilidades identificadas no passo anterior; "Desenvolver", o terceiro quarto que marca a fase onde os conceitos são criados, prototipados e testados; e "Entregar", último estágio que consiste na entrega final do projeto.

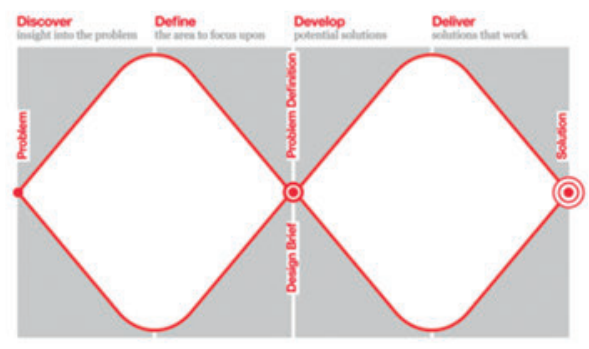

Gráfico 1 - Gráfico de execução do método Double Diamond. Fonte: Design Council (2015)

Para este trabalho, será considerada a etapa "Descobrir" como a pesquisa e análise de aspectos importantes e referenciais teóricos, onde será abordada a questão da representação em franquias transmídia; a etapa "Definir" como a delimitação da criação de concepts de personagens femininas para a HQ Medusas de The Rotfather; "Desenvolver" como os estudos feitos para a realização dos concepts; e por fim, "Entregar" como o resultado final gerado a partir da soma dos estudos feitos nas etapas anteriores, culminando no concept definitivo das personagens. 


\section{Representação e o universo transmídia}

Partindo do modelo Double Diamond do Design Council (2015) como referência, inicia-se neste tópico a fase de descobrimento através da investigação do mercado. A indústria do entretenimento percebeu nos últimos anos o poder das franquias transmídia (Stein, 2015). Notou-se que expandir e elaborar um universo narrativo desperta no público da nova geração um desejo de aprofundar seus conhecimentos sobre esse universo e consequentemente consumir mais de uma mesma narrativa.

Jovens consumidores se tornaram caçadores e coletores de informação, sentindo prazer em rastrear contextos de personagens e pontos de trama e fazer conexões entre diferentes textos dentro de uma mesma franquia (Jenkins, 2003).

Investir em narrativas transmídia tem se provado uma forma muito efetiva de gerar sentimentos de lealdade e dedicação do público na indústria do entretenimento. Segundo Jenkins (2003), criar novos níveis de conhecimento e experiência em uma franquia é uma maneira de renovar e manter o interesse do público na mesma, pois a torna mais complexa, sofisticada e mais gratificante para aqueles que a consomem. É também uma abordagem economicamente inteligente, pois um público cativado tem mais probabilidade de dedicar-se profundamente a um grupo seleto de franquias em vez de investir superficialmente em um número elevado de projetos pontuais (Stein, 2015. Fontão, 2019).

Uma das maneiras em que uma franquia conquista o interesse de seu público é investindo fortemente no desenvolvimento de personagens. O consumo de mídias, muitas vezes, além de uma busca por entretenimento, é uma válvula de escape da realidade para seus consumidores. $O$ público não quer apenas assistir uma aventura, e sim vivenciar tal momento. Uma das formas mais efetivas de proporcionar tal escape se apoia na ideia de projeção: fazer a audiência se identificar com o personagem a ponto que ela se sinta em sua pele (Rosa, 2018).

Partindo desse princípio, pode-se inferir que escrever e representar personagens de forma humanizada, dando-lhes conflitos, arcos e emoções realistas seja a chave para que o público se identifique mesmo com um personagem inserido em um contexto extravagante e desconhecido. Segundo Jesse Schell (2008), é importante conhecer sua audiência, saber o que ela gosta, como pensa, o que quer ver e como gostaria de ser representada. Dessa maneira, pode-se interpretar o conceito de projeção como uma via de mão dupla: é preciso que o criador se projete em sua audiência a fim de gerar um produto em que ela possa projetar-se de volta.

Porém, considerando que a indústria do entretenimento tem sido consistentemente dominada por criadores masculinos desde sua incepção, percebe-se que a representação de mulheres tem sido menos criteriosa do que a de homens. Em sua grande maioria, as mídias tendem a focar em pontos de vista e experiências masculinas, tornando a perspectiva feminina rasa ou inexistente (Rosa e Andrade, 2018).
A presença feminina - se existir - muitas vezes fica delegada a posições secundárias, pouco desenvolvidas e frequentemente sexualizadas. Essa constante representação pobre, por sua vez, tende a afastar o público feminino, e consequentemente muitas mídias passam a ser consideradas erroneamente como áreas exclusivamente masculinas. Esse fenômeno causa um ciclo vicioso de mulheres não serem consideradas um público válido para certas mídias e por consequência essas mídias em questão não terem interesse em desenvolver produtos com elas em foco (Rosa e Andrade, 2018).

\section{Desenvolvimento}

Nos tópicos a seguir detalha-se o contexto do G2E Grupo de Educação e Entretenimento - e seu universo fictício The Rotfather, assim como também a criação e inserção do spin-off Medusas e a importância de seu papel no projeto. O universo da franquia The Rotfather se passa em uma cidade subterrânea nos esgotos de Nova lorque, habitada por animais antropomorfos de diversas espécies onde a sociedade é regida por máfias, crime e grandes desigualdades sociais.

Os personagens do universo estão todos de alguma forma relacionados às máfias da cidade, cuja atividade criminosa gira em torno do tráfico do açúcar. Desta teia de relacionamentos encontra-se os chefes das famílias mafiosas e seus membros subordinados; sócios e parceiros que de alguma forma participam, mesmo que indiretamente, da atividade criminosa da cidade; membros privilegiados e marginalizados da sociedade, como socialites e prostitutas; entre outros personagens que compõe a complexa estrutura social de Faux City.

\section{The Rotfather e G2E - Grupo de Educação e Entretenimento}

The Rotfather é um projeto de pesquisa teórico-prático com 8 anos de existência e desenvolvimento, criado pelo G2E (Grupo de Educação e Entretenimento) inserido nos cursos de graduação de Design e de Animação do Departamento de Expressão Gráfica da Universidade Federal de Santa Catarina (UFSC) cuja proposta é analisar e simular as estratégias mercadológicas das franquias transmídia dos grandes conglomerados da indústria do entretenimento e aplicá-los em um estudo prático multidisciplinar.

Conforme dito anteriormente, as narrativas de The Rotfather convergem na cidade subterrânea de Faux City, situada nos esgotos de Nova lorque no início do século XX e habitada por uma diversificada população de animais antropomorfizados composta por ratos, baratas, aranhas, sapos, entre outros. As relações sociais se dão através de um intrínseca teia de classes e espécies, cujas vidas são permeadas por crimes, corrupção, tráfico e violência. 


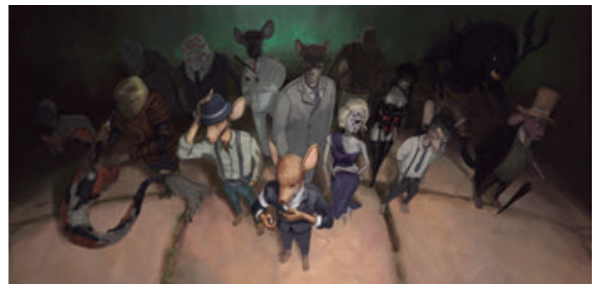

Figura 1 - Habitantes de Faux City. Fonte: arquivos The Rotfather.

Faux City é uma grande metrópole cortada por um rio de esgoto e marcada por desigualdades sociais que se manifestam geograficamente em sua estrutura: a cidade é dividida em quatro níveis, onde os mais baixos abrigam a população mais pobre e os mais altos a mais rica, com exceção do Morro do Açúcar que reverte essa lógica. Apesar de ser localizada no subterrâneo, a cidade é parcialmente banhada pela luz do sol através de três aberturas.

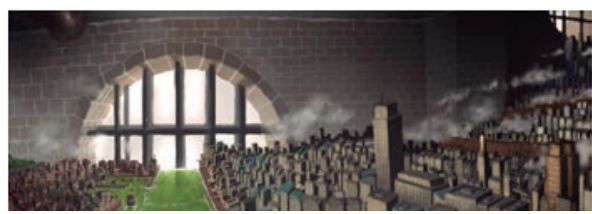

Figura 2 - Panorâmica de Faux City. Fonte: arquivos The Rotfather.

Dentre os produtos desenvolvidos pelo G2E para o The Rotfather estão histórias em quadrinhos, séries animadas, jogos analógicos e digitais, objetos colecionáveis, etc.

A organização do grupo se dá através de diversas células de desenvolvimento, cada qual com sua função específica, vinculadas as células de Storyworld (responsável pela coerência narrativa) e Artworld (responsável pela coerência visual), que conversam entre si para compor o pano de fundo de produção das obras de The Rotfather.

\section{A HQ Medusas}

Retomando o método Double Diamond (Design Council, 2015), inicia-se neste tópico a segunda etapa do modelo denominada "Definir", que consiste na gestão dos dados demonstrados nos tópicos anteriores, tanto do histórico da representação feminina em quadrinhos quando da assimilação do contexto narrativo de The Rotfather, com o intuito de administrar as informações e planejar o subsequente desenvolvimento do projeto.

Emmeioà crescente preocupação com representação feminina de qualidade na mídia, a equipe reponsável pela $\mathrm{HQ}$ Medusas da franquia fez uma análise interna de seu universo e chegou à conclusão que, assim como outras franquias da indústria do entretenimento, poderia fazer um trabalho mais profundo em questão de caracterização e representatividade feminina.

Uma das diretrizes principais da franquia The Rotfather, que visa a coesão da narrativa transmidiática, é a atenção especial dada à criação dos personagens. Acredita-se que o personagem não é apenas o responsável pela ação que faz a história acontecer, mas ele é tão humano e real em seus medos e crenças, quanto responsável por dar uma alma única à narrativa. (Nascimento, 2018)

A partir dessa análise de perfis, identificou-se que algumas das personagens femininas mais proeminentes do universo The Rotfather possuem perfis psicológicos, histórias de vida e concept art apoiados em questões de atração, sedução e sexualização, enquanto os personagens masculinos, em número, comparativamente, receberam um tratamento mais rebuscado em seu desenvolvimento, apresentando perfis mais profundos e diferenciados em histórias de vida mais complexas.

Exemplificando esse fato, a imagem abaixo mostra as personagens Madame Laura e Ninetta, respectivamente a dona e hostess do cabaré, e uma prostituta do Morro do Açúcar, onde pode ser observado um grande foco em sensualidade e erotização, sem grande expressão de outras características psicológicas.

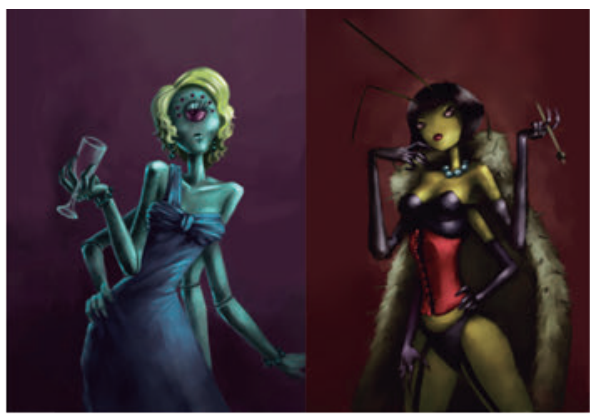

Figura 3 - Madame Laura e Ninetta. Fonte: arquivos The Rotfather.

Logo, as membros femininas do desenvolvimento da $\mathrm{HQ}$ decidiram apresentar como narrativa transmidiatica da franquia, a história de luta de uma uma gangue formada apenas por fêmeas habitantes de Faux City, intitulada Medusas, que inicialmente se juntaram por ideais de sororidade e proteção, e aos poucos evoluíram silenciosamente entre as máfias, compostas majoritariamente por homens, conquistando poder, independência e seu espaço através do tráfico de sua droga exclusiva: o adoçante bebível, em oposição à sua fórmula anterior que só poderia ser consumida de maneira injetável.

A história é contada através de diferentes linhas do tempo, abordando os anos de 1898, 1914, 1915, 1916 e 1933.

Cada timeline conta a narrativa através de diversas personagens e pontos de vistas, e o presente trabalho que se apresenta neste artigo demonstra a construção dos concepts de personagens do grupo protagonista de 1898, HQ inicial do conjunto das demais.

Este recorte acompanha a formação do grupo Medusa, sua divergência entre uma linha de frente de resistência mais pacífica e uma de guerrilha e 
confronto, e por fim o encontro de um equilíbrio entre esses arquétipos conflitantes através de um terceiro partido neutro, tornando a organização interna do grupo em uma que consiste em uma tríade de poder. O conflito entre as linhas de ataque e resistência é abordado toltamente na linha do tempo de 1898 .

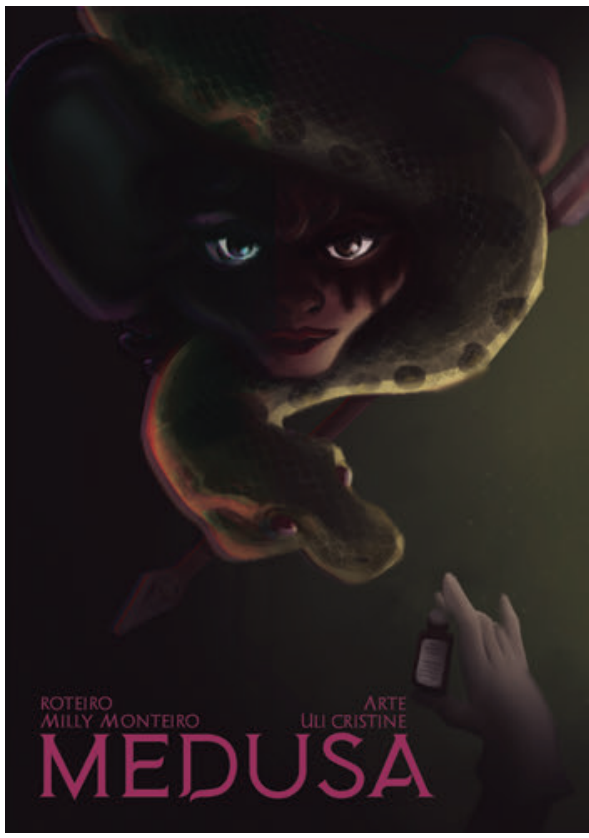

Figura 4 - Pôster das Medusas. Fonte: Uli Cristine

\section{Referências históricas e visuais}

$\mathrm{O}$ ano em que a primeira geração das Medusas se passa, 1898, um período histórico em que várias nações do mundo se encontram em fases de prosperidade e crescimento econômico após temporadas marcadas por guerras e sofrimento.

A Inglaterra se encontra nos anos finais da Era Vitoriana (1837-1901), com o reinado da Rainha Vitória promovendo a chamada "Pax Britannica" marcada pelo ápice da Revolução Industrial e a ascensão da classe média. De acordo com Lessa (2005), Pax Britannica define o período de paz relativa no continente europeu, e por consequência no restante do mundo, que durou de 1815 a 1914, quando inicia a Primeira Guerra Mundial. Na França, a Belle Époque se refere ao período após a guerra Franco-Prussiana até a Primeira Guerra Mundial, conhecida como uma era de abundância, arte, cultura e avanços tecnológicos. O uso da eletricidade não apenas impulsiona a atividade fabril como também permite às pessoas desenvolverem mais hábitos sociais noturnos como bailes e o simples caminhar pelas ruas que agora eram iluminadas e consideradas mais seguras. A cultura do consumo se desenvolve atrelada ao avanço tecnológico, pois além de produtos estarem sendo criados mais rapidamente, passam a ser anunciados e vendidos com maior velocidade. A medida que os dias se tornam mais longos e as horas de trabalho mais curtas pelo uso da luz elétrica, ocorre um aumento da busca por atividades de lazer, culminando na prática de esportes profissionais e criação de mais parques, teatros etc.

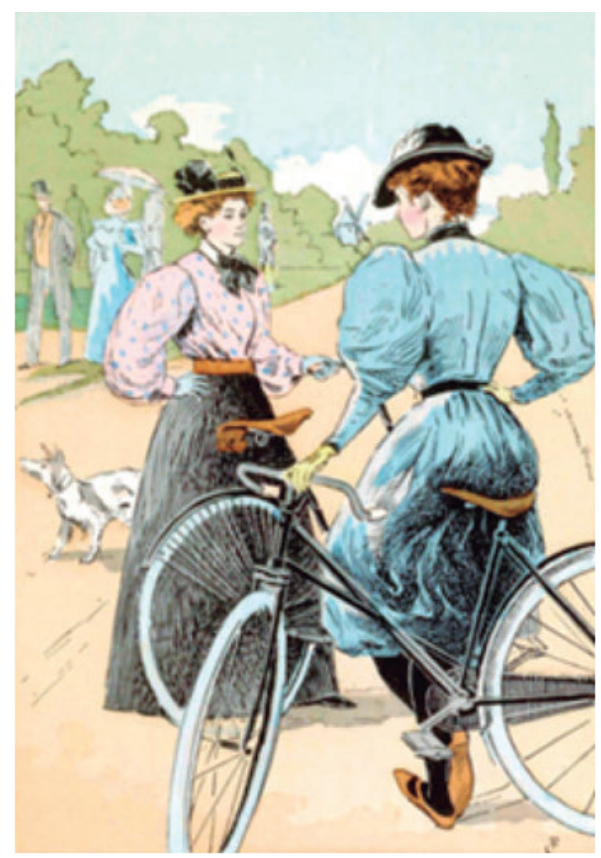

Figura 5 - "The Ladies of the Wheel ". Fonte: François Courboin (1896)

Nos Estados Unidos, o período entre 1870 e 1900 ficou conhecido como Era Dourada (ou "Gilded Age" em seu idioma original). Cerca de 30 anos após a Guerra Civil americana, o país havia se transformado em uma grande potência econômica ao mesmo tempo que o abismo social entre classes se tornava cada vez maior. A rápida industrialização das cidades, novas tecnologias e a integração gerada pela implementação de ferrovias conectando todo o país veio a mudar totalmente o estilo de vida americano. O que antes se tratava de uma sociedade majoritariamente rural onde as relações sociais e de consumo se davam pela proximidade geográfica e onde o comércio local e familiar prosperava rapidamente, se tornou uma sociedade marcada pelo avanço industrial, expansões comerciais e migrações em massa para as grandes cidades em busca de novas oportunidades de vida. Rapidamente fica clara a distinção de duas classes: a alta sociedade e a classe operária. Enquanto a primeira retia a maior parte dos recursos financeiros e ocupava seu tempo com festa chiques, gastos extravagantes e uma atmosfera geral de ostentação, a segunda trabalhava exaustivamente para conseguir se alimentar. A imagem abaixo, "The Bosses of Senate" 
de Joseph Keppler, exemplifica através de charge o crescente abismo entre classes e a maneira em que a classe alta explorava a mão de obra da classe trabalhadora durante o período da Era Dourada:

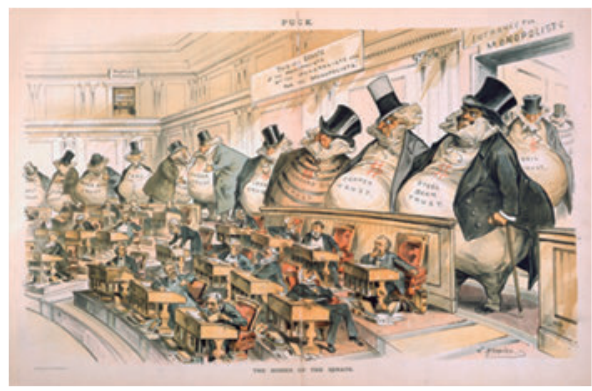

Figura 6 - "The Bosses of Senate". Fonte: Joseph Keppler (1889)

O estilo artístico e arquitetônico vigente da época foi o Art Nouveau (1880 - 1920), cuja estética se inspirava em formas da natureza como folhagens, flores e linhas curvas e ascendentes que representam movimento, como o das árvores e do fogo, com grande influência de artes japonesas, barroco e rococó. Presente nas obras de arte, nas construções e nos objetos decorativos, o Art Nouveau é facilmente identificado pela sua elegância, opulência e natureza exótica, cujo excesso de formas elaboradas e linhas entrelaçadas era um reflexo da ostentação e estado de espírito da alta classe dominante da sociedade. Segundo Jeremy Howard (1996), os artistas do Art Nouveau tinham como objetivo criar formas orgânicas e distintas, com foco em natureza e ritmo.

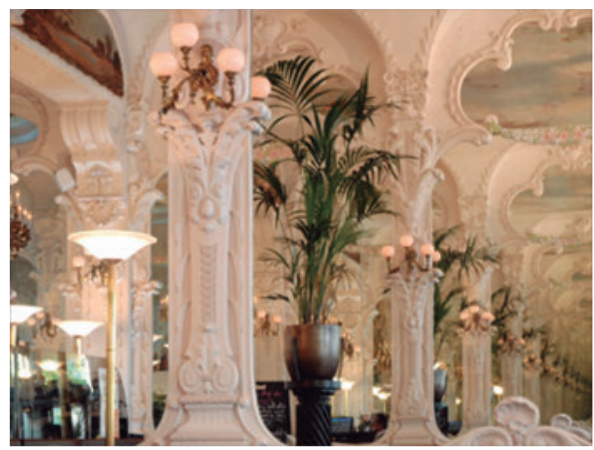

Figura 7 - Le Grand Café, Place d'Allier, Moulins, França. Fonte: Base de dados das autoras (2019)

O Realismo, movimento artístico muito popular na Europa, sobretudo na França, acontece simultaneamente às mudanças da sociedade, em especial a Revolução Industrial. Como sugerido pelo nome, o Realismo tem como objetivo retratar na arte a imagem mais fiel possível à realidade, e mostrar a sociedade como ela realmente era, sem floreios, cores vibrantes ou romantização do cotidiano.

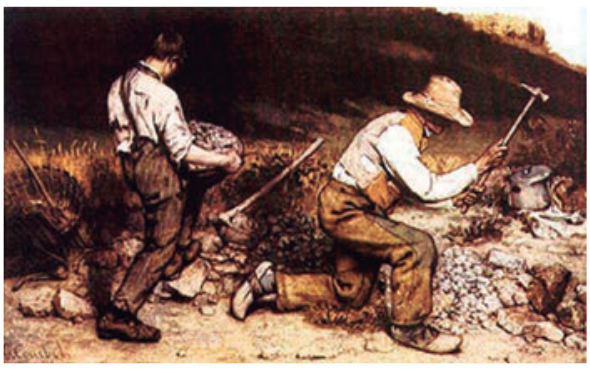

Figura 8 - Pintura realista "Os Quebradores de Pedra". Fonte: Gustave Courbet (1849)

Em contrapartida, o Impressionismo buscava quebrar com os conceitos do realismo, focando em impressão da luz, cores e movimento, apresentando uma versão mais fantasiosa da realidade.

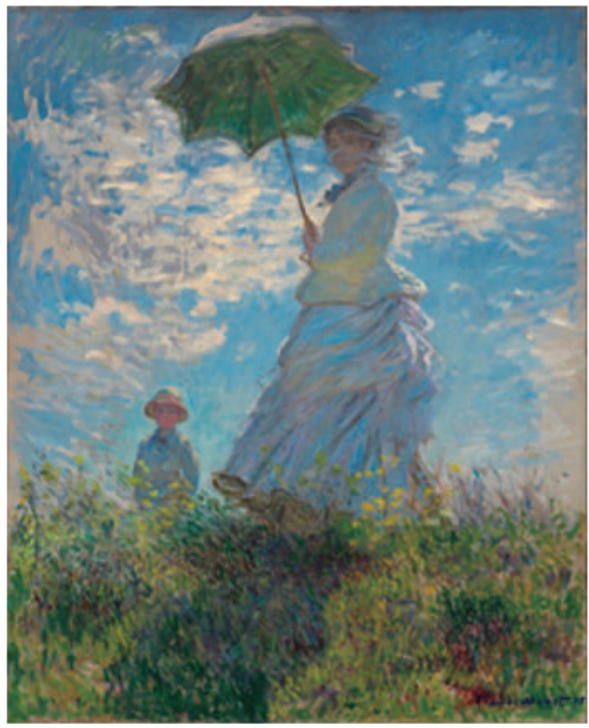

Figura 9- Pintura impressionista "Mulher com Sombrinha". Fonte: Claude Monet (1875)

O Papel da Mulher na Sociedade do Século XIX

O século XIX foi marcado por uma mudança de ideologia e posicionamento da mulher para com a sociedade e do surgimento de diversos movimentos sufragistas, como o Women's Christian Temperance Union (União da Temperança Cristã das Mulheres, em tradução livre, ou WCTU) nos Estados Unidos.

Não havia muitas opções de independência doméstica e/ou financeira para a população feminina da época. Casamento, maternidade e trabalhos como operárias ou vendedoras, cobriam parte do limitado leque de escolhas de uma moça do século XIX. As mulheres de classes mais altas eram desencorajadas a buscarem uma carreira, e os salários mínimos e condições insalubres de ambientes de trabalho 
como as fábricas deixavam essa ideia ainda menos interessante. A ideia de mulheres receberem salários não era considerada natural, fazendo com que elas fossem forçadas a depender financeiramente de seus pais e subsequentemente de seus maridos. (Cruea, 2005).

Porém, ao longo do século, pode-se observar uma mudança no posicionamento da mulher na sociedade através das definições opositivas True Woman (verdadeira mulher), Real Woman (mulher real) e New Woman (nova mulher). Da década de 1820 até 1860 , o ideal feminino era designado "True Woman", e resumia-se à ideia de que submissão, fragilidade, autocontrole, pureza e domesticidade eram virtudes próprias da natureza feminina (Welter, 1976). A mulher era incentivada a ter uma forte ligação religiosa, manter sua virgindade até o casamento, demonstrar delicadeza e piedade, ser submissa ao marido e limitar suas atividades cotidianas ao ambiente doméstico, sendo desestimulada a buscar qualquer trabalho que pudesse ser detrimental aos "charmes de sua delicadeza feminina" (Welter, 1966).

Esse ideal, é claro, só era uma possibilidade para a mulher de classe média a alta. A população feminina de classe baixa, a quem trabalhar para ajudar no sustento familiar era uma necessidade e não uma opção, foi quem deu origem ao termo Real Woman (ou Public Woman), nova ideologia feminina presente entre as décadas de 1860 e 1880. A Guerra Civil Americana criou a necessidade da mão de obra feminina devido ao grande número de homens convocados para a batalha. Além disso, os danos colaterais da guerra geraram um elevado número de viúvas, solteiras com poucas opções de matrimônio e esposas cujos maridos voltaram deficientes. Como resultado, a parcela da população mais apta a ocupar os postos de trabalho e prover para suas família passou a ser de mulheres, cujo número excedia exacerbadamente o de homens nos Estados Unidos. As mulheres da época, vendo-se ocupar um papel na sociedade antes exclusivo de homens e percebendo sua própria competência, incorporaram o ideal da Real Woman: uma mulher que passava a se ver igual a homens tanto em capacidade física quanto intelectual e que portanto passava a requerer também, em pequenas doses, igual tratamento e direitos.

A Real Woman de 1860 e 1870 deu a luz então à New Woman de 1880 e 1890, considerada ainda mais ambiciosa e assertiva que sua contraparte anterior. Rejeitando casamento e maternidade, a New Woman não só buscava ocupar o mercado de trabalho como também sua liberdade sexual e desenvolvimento intelectual. As mulheres da época passaram a ocupar universidades e buscar carreiras fora dos ramos "aceitáveis" (costureira, professora, enfermeira), além de demandar mais oportunidades semelhantes às dos homens que suas predecessoras, no que dizia respeito a direitos civis, políticos, econômicos, trabalhistas e educacionais.

É com base nesse contexto histórico e social que se passa a era das Medusas - HQ 01. Por toda a narrativa, pode-se perceber ecos remanescentes da True
Woman e da Real Woman, mas os ideais feministas e sufragistas da New Woman são a voz mais alta que se ouve por toda a história e servem como pano de fundo para a criação do grupo feminino Medusa com focos de liberdade, proteção e sororidade.

\section{Concepts}

Voltando ao método Double Diamond do Design Council (2015), inicia-se então a etapa Desenvolver, onde os conhecimentos agregados nas fases anteriores guiam a criação "de fato" dos concepts das personagens - True Woman; Real, Woman; e New Woman. Para adequar as vestimentas das personagens à época em que se passa a história, foi aplicado um estudo histórico da idumentária.

\section{Perfil e Concept da Rita}

Rita é uma rata de pelagem ruiva lisa pertencente a uma família rica dona das redes de farmácia de Faux City. De origem inglesa, Rita se encaixa no padrão europeu de beleza e etiqueta, representando a perfeita dama sofisticada que a alta sociedade espera. Casou-se muito jovem com um homem com o dobro de sua idade, e aos 20 anos deu à luz a sua primeira e única filha, Cosette.

No começo da história, Rita se encaixa no padrão True Woman, ou seja, uma mulher que depende totalmente do marido e segue os padrões de beleza e comportamento impostos pela sociedade.

Como mulher séria e discreta, Rita não costuma sair de sua zona de conforto a não ser que a situação se mostre necessária. Sua vida de luxo e privilégios a cega para os problemas sociais enfrentados por outras pessoas, e ela reage às injustiças alheias com indiferença e desinteresse. Rita é apática e materialista, e preza muito por status e reputação. Seu estado de espírito em público sempre se mostra frio e impenetrável, sem deixar transparecer emoções.

O gráfico abaixo demonstra um resumo de sua personalidade através da análise de sua zona de conforto:

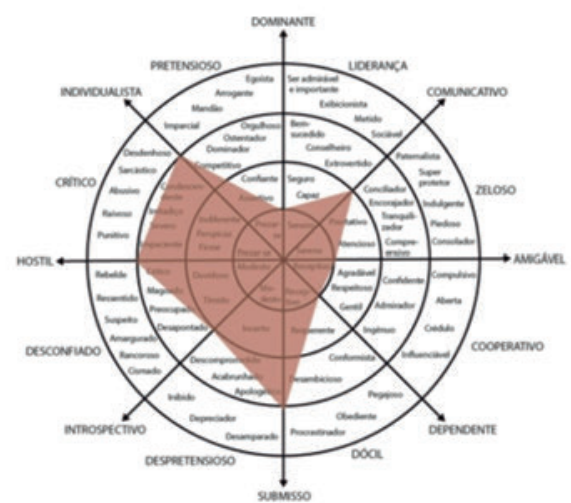

Gráfico 2- Zona de conforto de Rita. Fonte: Hemilly Monteiro e Maielle Ramos 
Rita sempre se interessou por alquimia, o que a levou a ingressar na Universidade Stein para cursar química. É lá que ela passa a conviver pela primeira vez na vida com mulheres de diferentes classes sociais, estilos e ideologias, e onde também, através de suas novas amizades, tem seu primeiro contato com o grupo Medusa. No futuro Rita virá a auxiliar as Medusas no tráfico de adoçante através da venda clandestina do mesmo em sua rede de farmácias.

Com base em sua personalidade, o vestuário de Rita seguiria o padrão feminino ao extremo. Conformada com os padrões da sociedade, Rita se porta como uma dama e sempre se apresenta impecavelmente com penteados elegantes e roupas seguindo a moda parisiense, sem ousar ou desviar do que seria considerado o ideal feminino da época.

Antes de começar qualquer pesquisa e desenvolvimento baseado nas personalidades distintas, foi necessário estudar a anatomia e referências presentes nos arquivos de The Rotfather para estabelecer antes de mais nada a estrutura corporal das personagens.

Neste universo, os ratos são os animais que mais se assemelham à anatomia humana, sendo mamíferos que possuem o mesmo número de membros e olhos, com o diferencial da cauda. O desafio nesse caso foi estabelecer a estrutura craniana da personagem. Um concept de personagem realizado anteriormente para uma personagem rata para outro produto do universo The Rotfather, serviu como ponto de partida. Vale ressaltar que antes da realização deste concept, ainda não havia nenhum concept de personagens femininas desta espécie no universo, limitando-se as referências apenas de guarda-roupa, penteados e acessórios históricos.

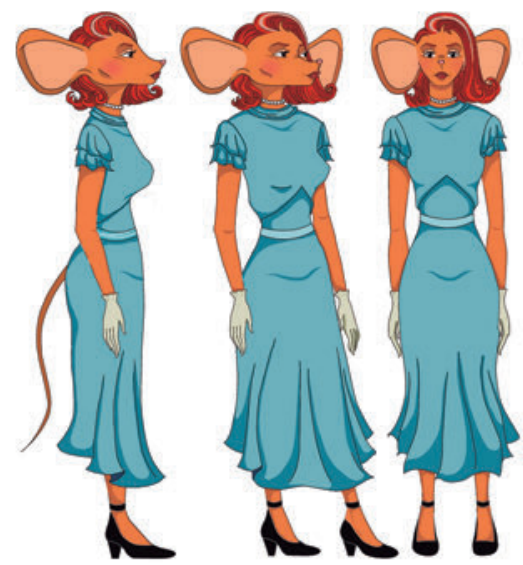

Figura 10 - Concept para The Rotfather, era 1930. Fonte: as autoras.
O concept mostrado na figura 10 segue a estrutura craniana de um rato da vida real, porém ele apresenta problemas quando emparelhado com a anatomia corporal humana. O formato da cabeça passa a sensação de esta ser pesada demais para ser sustentada pelo corpo, criando uma impressão geral de desequilíbrio compositivo. A vista frontal difere muito das demais, pois é muito difícil contemplar o volume do focinho deste ângulo, dando a impressão de que são duas personagens completamente diferentes. As orelhas grandes dificultam a inserção de cabelos compridos e acessórios como chapéus. Por fim, o focinho da vista $3 / 4$ gerou associações indesejáveis a outras espécies e personagens - mais especificamente, focinho de lobo e de cachorro, e acoplamento com as orelhas grandes, trazendo uma semelhança estranha com o personagem Dumbo da Disney. A solução encontrada foi achatar o focinho e diminuir as orelhas, aproximando mais o crânio do rato ao humano. Como diferencial da espécie, as orelhas ainda mantém-se maior que as humanas e o nariz é em forma de focinho.

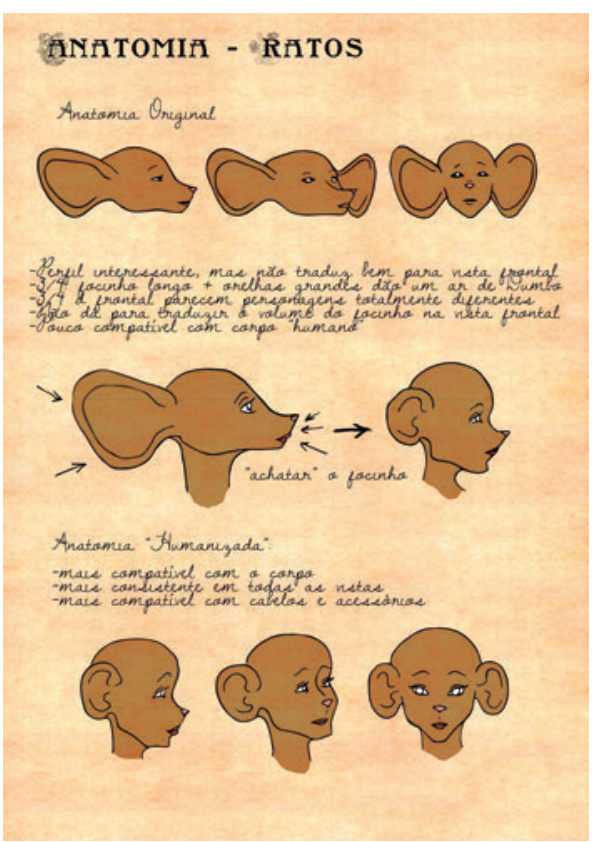

Figura 11 - Estudo de anatomia craniana para ratos do universo The Rotfather. Fonte: as autoras. 
Observou-se que a nova proposta combinava melhor com a anatomia corporal, com um peso melhor distribuído, promovendo um encaixe mais adequado do pescoço com a cabeça.

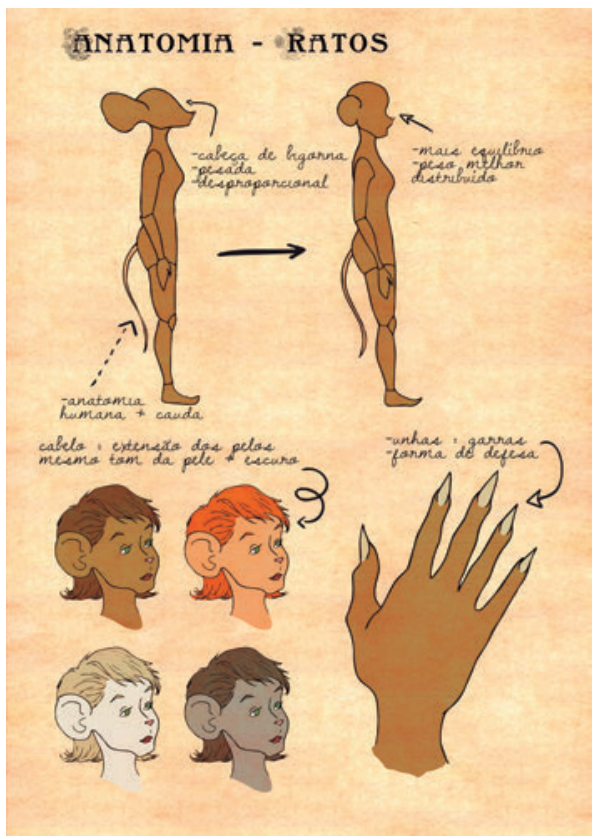

Figura 12 - Estudo de anatomia corporal de ratos do universo The Rotfather. Fonte: as autoras.

Para reter a identidade de rato, além da cauda e orelhas maiores, transformou-se as unhas em garras, elemento que permite defesa e ataque, e que é usado na vida real para auxílio de caça e alimentação. Além disso, a questão capilar foi estabelecida como sendo uma extensão dos pelos, apresentando-se em uma tonalidade mais escura que a pele para simular a humana.

Tendo estabelecido a anatomia, partiu-se para a questão dos concepts. Foram criados como apoio projetual dois painéis semânticos, um com palavras e outro com imagens, para estabelecer Mood Boards que sintetizem a informação dos perfis e guiem a criação com base em referências visuais. O painel de palavras foi criado por associações feitas a partir da leitura dos perfis das personagens, com o objetivo de sintetizar sua personalidade em um quadro de rápida consulta. No caso de Rita, o resultado foi o seguinte.

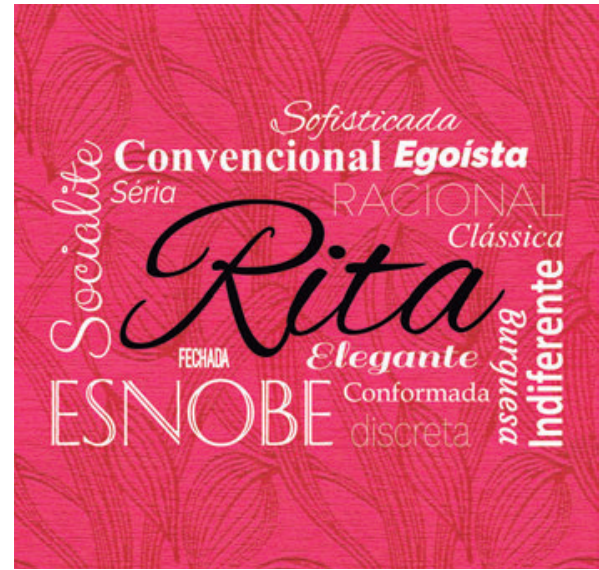

Figura 13 - Painel semântico de palavras da Rita. Fonte: as autoras.

O segundo painel tinha referências visuais que compõem associações feitas a partir da leitura dos perfis.

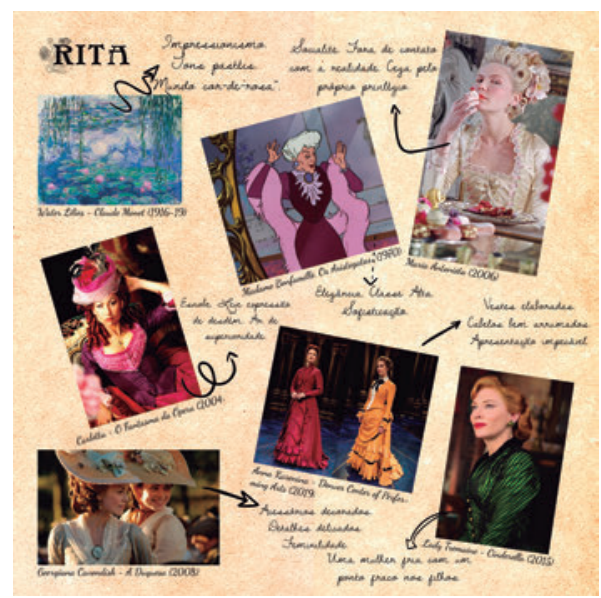

Figura 14 - Painel semântico de imagens da Rita. Fonte: as autoras.

As maiores influências psicológicas foram a interpretação da atriz Kirsten Dunst de Maria Antonieta (2006), com a característica comum com Rita de ambas serem socialites alienadas aos problemas alheios e cegas pelo próprio privilégio; a personagem Carlotta da peça O Fantasma da Ópera (2004) no quesito de apresentarem personalidades esnobes que se consideram superiores aos demais; e Lady Tremaine do filme Cinderella (2015), no sentido de serem ambas mulheres frias de alta classe que tem um ponto fraco em seus filhos, com quem genuinamente se importam. Esta última serve também como referência visual e de estilo, juntamente com Madama Bonfamille (Os Aristogatas, 1970), o figurino 
de Anna Karenina da companhia Denver Center of Performing Arts (2019), e a interpretação da atriz Keira Knightley da duquesa Georgiana Cavendish (2008), sendo todas personagens da alta sociedade que sempre se apresentam impecavelmente com roupas elegantes e femininas.

Rita é o tipo de mulher que jamais sairia de casa com seus cabelos desarrumados, então presume-se que ela se daria ao trabalho de fazer penteados para complementar sua aparência. Alguns testes foram feitos, e estabeleceu-se que o estilo que mais combinava com sua personalidade seria de um coque elegante, por ser prático e sofisticado e passar uma ideia de seriedade. Além disso, cabelos presos poderia significar sinais de organização e restrição, adequados para uma personagem presa pelas expectativas da sociedade. Por esse motivo, a personagem só aparece de cabelos soltos em momentos de intimidade e/ ou vulnerabilidade.

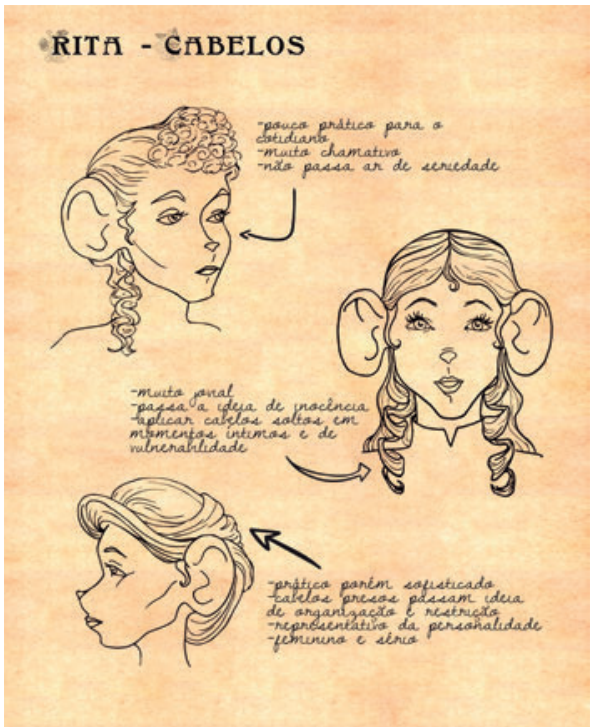

Figura 15 - Estudo de penteados de Rita. Fonte: as autoras.

Para referências de peças de vestuário, foi usado o catálogo da Rede Sears, de 1898. Sendo uma mulher clássica da época, Rita se veste seguindo a moda, usando roupas femininas misturando cores vivas e tons pastéis, com a intenção de ressaltar a bolha social em que esta personagem vive. Os tons vivos são representativos de sua realidade intocada pela sujeira e sofrimento das ruas da cidade, enquanto os tons pastéis fazem uma alusão ao fato de ela viver em um "mundo cor-de-rosa". Sendo um membro da classe alta, Rita traja os melhores tecidos, sempre combinando suas roupas elegantes com um chapéu diferente. Os detalhes delicados e adornos sofisticados que usa em suas peças cementam sua firme posição como uma dama da alta sociedade.

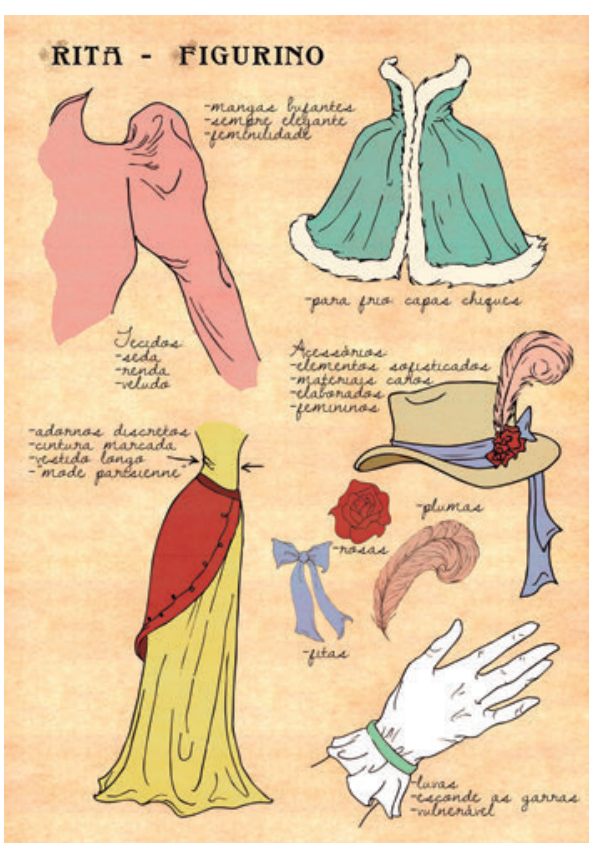

Figura 16 - Estudo de figurino de Rita. Fonte: as autoras.

Criou-se um painel de elementos contendo a paleta cromática associada à personagem, isto é, tons pasteis e cores vivas, e um conjunto de texturas que representam os tecidos mais comumente usados em seu vestuário. São eles, de cima para baixo e da esquerda para a direita: Renda, veludo, seda, bordados e pele.

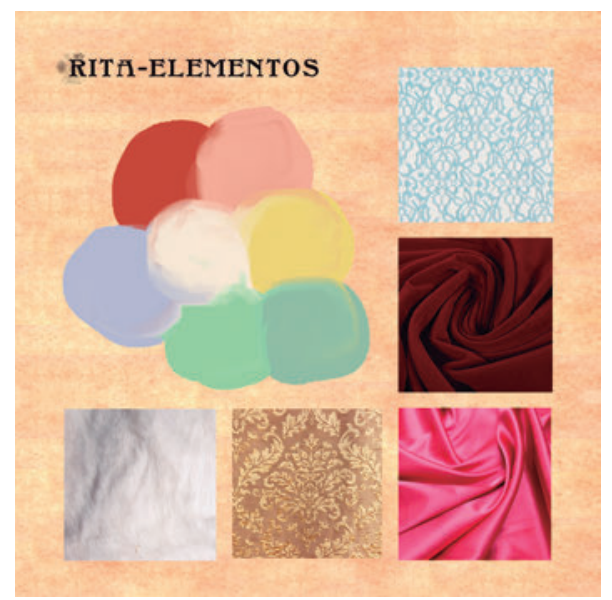

Figura 17 - de paleta cromática e texturas da Rita. Fonte: as autoras. 
Por fim, foram feitos estudos de expressão da personagem. Rita é uma mulher muito séria e discreta, raramente deixando transparecer emoções quando está em público. Ainda assim, pode-se perceber um leve ar de superioridade em sua expressão padrão. Anda com o rosto sutilmente levantado, o que a deixa com aparência de "nariz empinado", literal e figurativamente. Apenas em ambientes particulares em que se sente segura, ela deixa suas emoções emergirem.

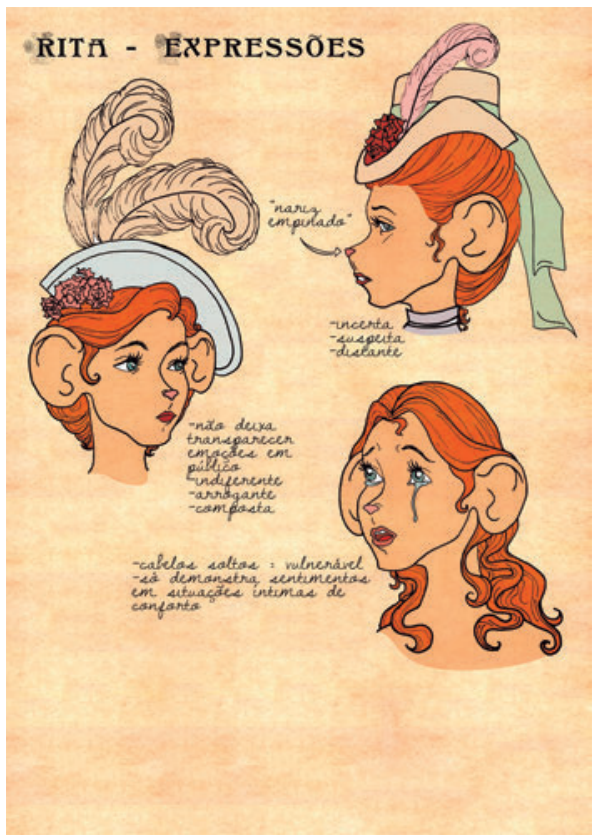

Figura 18 - Estudo de expressões de Rita. Fonte: as autoras.

A partir da pesquisa e da realização dos testes e especificações, parte-se para a etapa final do método Double Diamond "Entregar", como sendo o "concept final" da personagem Rita, com a aplicação dos estudos e elementos estéticos estabelecidos, conforme as imagens a seguir:

\section{RITA - CONCEPT}

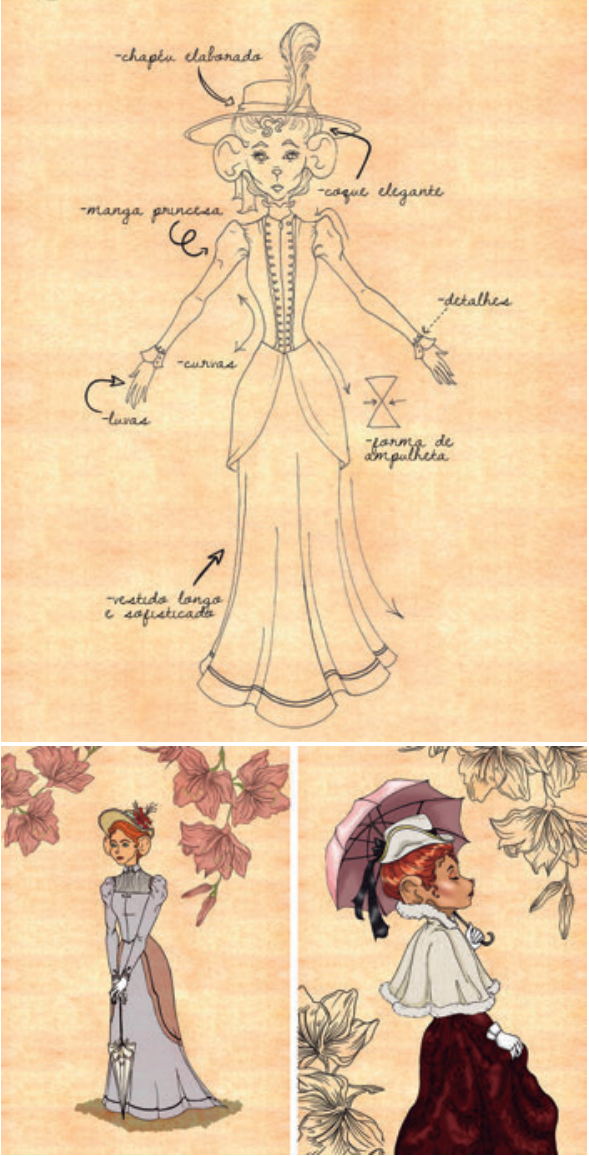

Figura 19 - Concepts finais preto e branco e coloridos da personagem Rita. Fonte: as autoras.

\section{Perfil e Concept da Aurelia}

Indesejada desde o ventre, Aurelia é uma rata comum de esgoto de pelagem escura e olhos castanhos, fruto de um estupro sofrido por sua mãe. Não é tão rica quanto Rita mas pertence a uma família abastada dona de muitos terrenos na cidade. Filha de uma nativa de Faux City e neta de uma das fundadoras do grupo feminino da cidade, Aurelia desde pequena teve contato com ideias libertárias de cunho feminista.

Explosiva e carismática, Aurelia serviu de inspiração para muitas moças feministas de Faux City durante sua juventude. De personalidade forte, opiniões formadas e natureza impulsiva, Aurelia fala o que pensa e não tem medo de puxar briga. Movida pela sua própria moral questionável, ela luta por seus ideais sem se importar com as consequências ou com quem se machucar ao longo do caminho. Para ela "os fins justificam os meios" e o caos que causar é em prol de um bem maior. $\mathrm{O}$ 
gráfico abaixo demonstra as partes fortes de sua personalidade e a forma como a personagem age a partir da análise de sua zona de conforto:

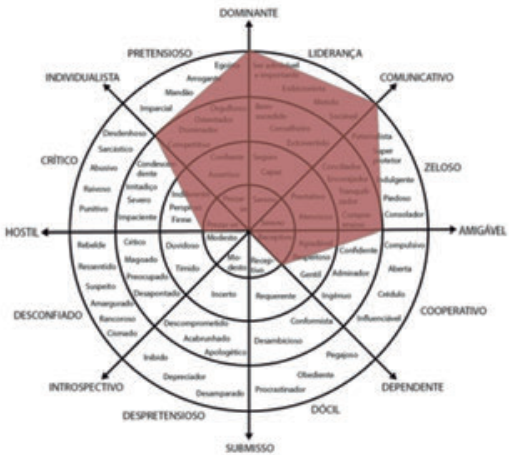

Gráfico 3 - Zona de conforto de Aurelia. Fonte: Hemilly Monteiro e Maielle Ramos. (2018)

Após o suicídio de sua mãe, Aurelia finalmente descobre a história de sua origem e o trauma a leva a cortar todo o seu cabelo e cria dentro dela um nojo à ideia de maternidade. Entra na faculdade como estudante de jornalismo e passa a fazer parte da linha radical da resistência feminina, sendo uma das figuras que faz o grupo passar a questionar se sua abordagem pacífica realmente é a linha de ação adequada frente à ameaça de um serial killer que ataca mulheres. Aurelia é uma grande representante do perfil da New Woman, sendo dona de uma personalidade combativa que rejeita os ideais femininos e limites impostos pela sociedade. Não tem medo de falar sua opinião e lutar por seu espaço e direitos.

Considerando que Aurelia e Rita são da mesma espécie e tendo como base os estudos anatômicos mostrados no tópico anterior, passou-se direto para a geração de painéis baseados no perfil da personagem.

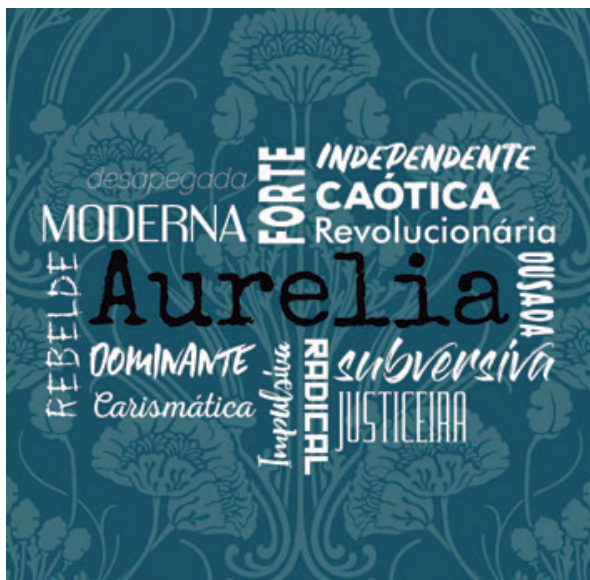

Figura 20 - Painel semântico de palavras da Aurelia. Fonte: as autoras.
Em seguida, o painel visual baseado em personalidades que serviram de inspiração e referência para a criação de Aurelia.

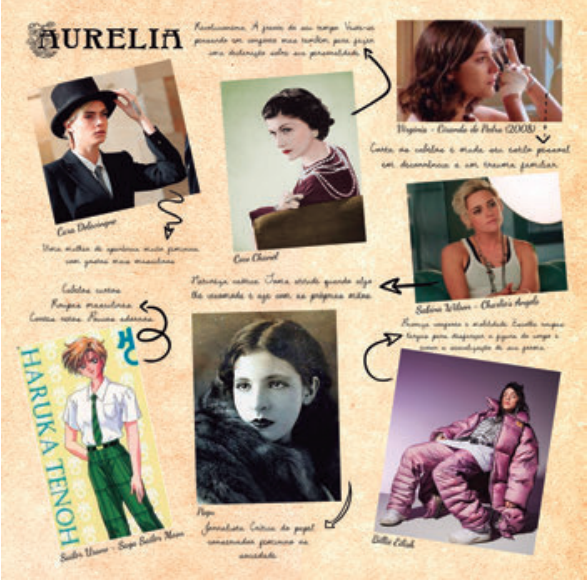

Figura 21 - Painel semântico de imagens da Aurelia. Fonte: as autoras.

No caso de Aurelia, as referências psicológicas e visuais acabaram se mesclando um pouco. Assim como Coco Chanel, Aurelia pode ser considerada uma mulher revolucionária e à frente do seu tempo cujas escolhas de vestuário fazem com que ela se destaque entre as demais. Assim como a modelo Cara Delevingne e a personagem Sailor Urano (saga em animação japonesa 2D de título Sailor Moon), Aurelia é uma mulher muito bonita e com feições femininas, com uma preferência por roupas com cortes retos e mais masculinos. Sua escolha por usar roupas largas e confortáveis que não marquem o corpo sa assemelha à cantora americana Billie Eilish. Sua tendência a tomar ação a aproxima a personagem Sabina Wilson do filme Charlie's Angels (2019), e sua decisão de cortar todo o cabelo em resposta a uma traumática revelação familiar lembra muito o arco narrativo da personagem Virgínia da telenovela brasileira Ciranda de Pedra (2008). A inspiração que mais se assemelha à Aurelia em termos de personalidade e ideologia é a musa do movimento modernista Pagu. Assim como Pagu, Aurelia era uma jornalista que criticava os ideais conservadores impostos à mulher na sociedade.

Nos estudos estéticos, o primeiro modelo testado para o cabelo foi um corte estilo moicano, com madeixas mais baixas na lateral da cabeça e um "topete" volumoso. Apesar de proporcionar uma silhueta muito interessante à personagem, o corte moicano é pouco feminino e poderia passar a impressão de que ela estaria fugindo de sua identidade como mulher. Além disso, seu estilo não se encaixava com o período histórico, sendo muito moderno e podendo gerar dificuldade para a adição de acessórios como chapéus. A segunda alternativa 
foi a de raspar a cabeça da personagem, porém esse modelo seria ainda mais masculino e geraria mais problemas anacrônicos que o anterior, além de causar estranhamento pelo contraste de um corpo coberto de pelos com uma cabeça completamente lisa. A alternativa final escolhida para Aurelia foi a de Ihe dar um "pixie cut", pois a franja emparelhada com o cabelo curto poderia gerar o equilíbrio ideal entre o masculino e o feminino. Esse corte de cabelo em questão também apresentava movimento, passando um ar de dinamismo e sagacidade para a personagem.

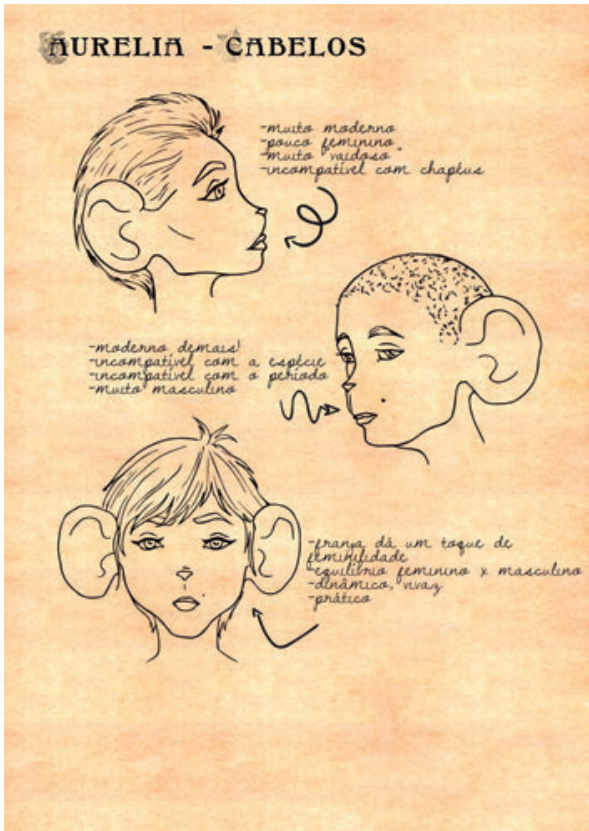

Figura 22 - Estudo de penteados de Aurelia. Fonte: as autoras.

Em contraste com Rita, Aurelia se veste ignorando totalmente o ideal de feminilidade da época. Apesar de não se opor ao uso de saias, prefere calças por considerá-las mais práticas e confortáveis. Só usa roupas frouxas que não marcam as curvas do corpo, resultando em peças com bastante dobras que dão a impressão de que não foram feitas para seu tamanho. Combina o uso de camisas sociais com terninhos e sobretudos largos de corte reto com chapéus mais masculinizados e sem adornos. Mantém alguns toques sutis de feminilidade em seus acessórios, como o uso de laços em alguns detalhes de suas roupas, fitas em vez de gravatas e brincos pequenos. Aurelia usa cores sóbrias e dessaturadas, dando preferência a cinzas, azuis, verdes envelhecidos e marrons.

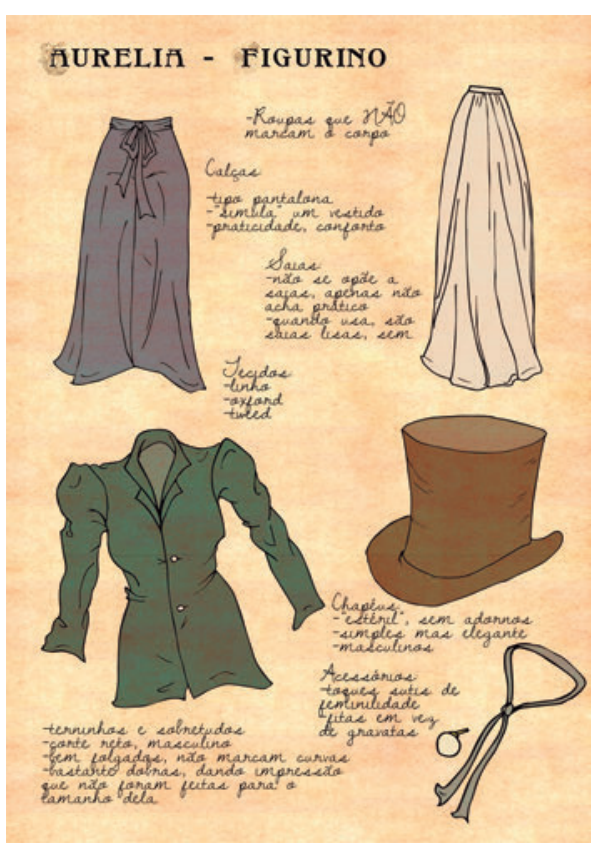

Figura 23 - Estudo de figurino de Aurelia. Fonte: as autoras.

Abaixo segue o painel semântico de elementos visuais contendo a paleta de cores que Aurelia veste juntamente com um conjunto de texturas e tecidos associados às suas roupas. São eles, de cima para baixo e da esquerda para a direita: linho, tweed, oxford, estampa vichy e couro.

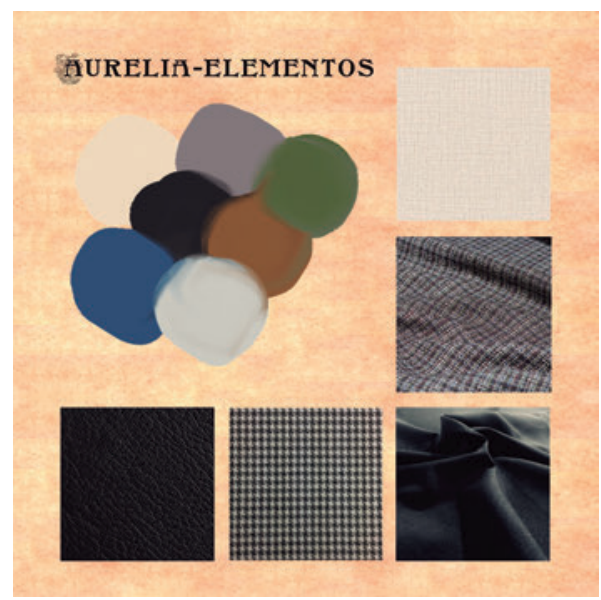

Figura 24 - Painel de paleta cromática e texturas da Aurelia. Fonte: as autoras. 
Em relação às suas emoções, Aurelia não esconde o que sente, com suas expressões demonstrando exatamente seu estado de espírito. É uma personagem que vive suas emoções "à flor da pele", todas elas se fazendo perceptíveis, independente de sua natureza. Quando bem-humorada, seu sorriso é cativante e sua atitude carismática. Quando irritada,

fala o que pensa e não foge de conflito, estando sempre pronta para uma briga. Sua tristeza também é óbvia e aparece estampada em sua face.

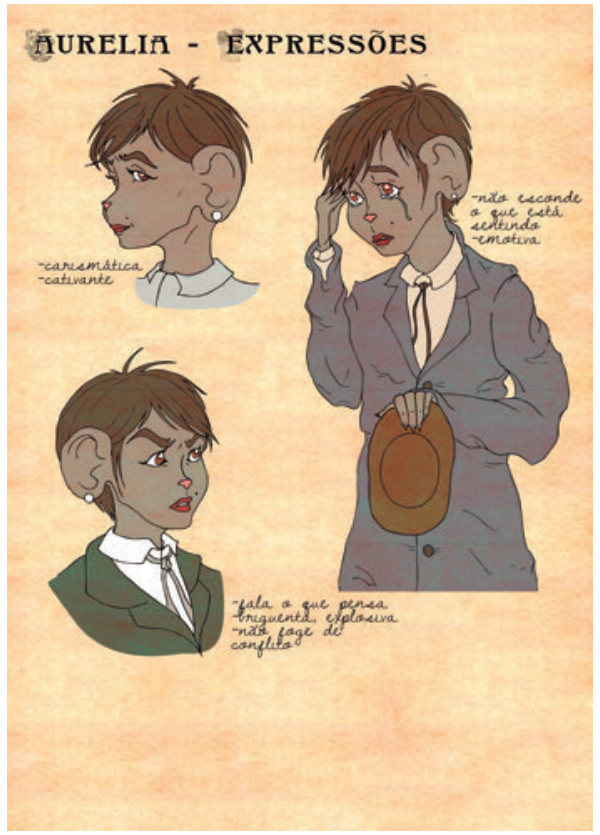

Figura 25 - Estudo de expressões de Aurelia. Fonte: as autoras.

A etapa "Entregar" do método Double Diamond em relação à personagem Aurelia, consiste na junção de todos esses elementos visuais nos concepts mostrados a seguir.

\section{RUURELIA - CONCEPT}
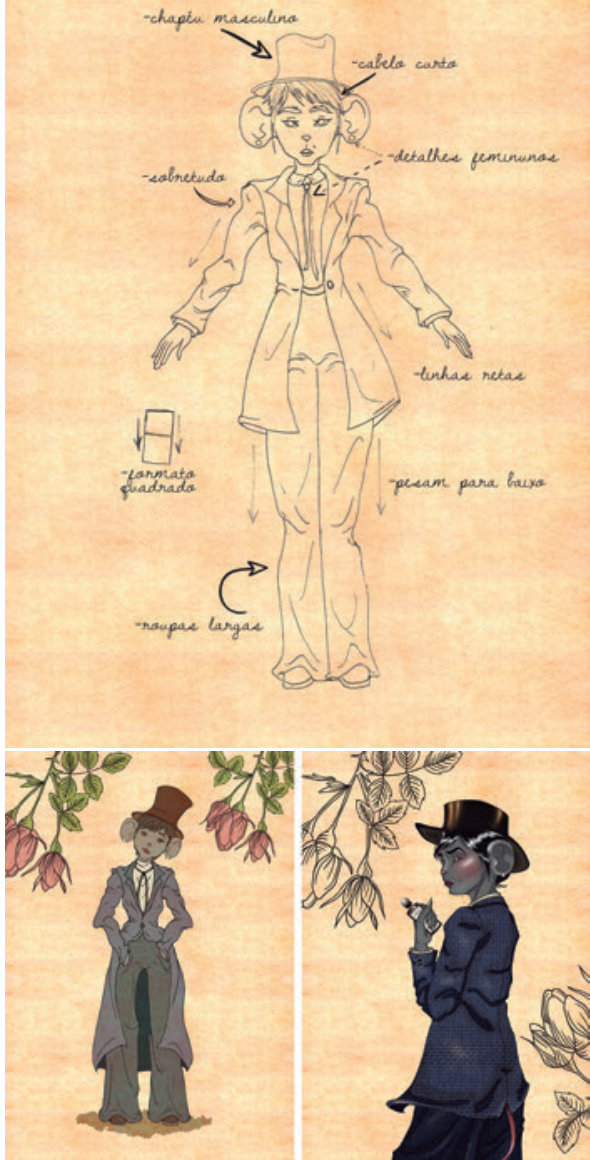

Figura 26 - Concept - Preto e braco e coloridos da personagem Aurelia. Fonte: as autoras.

\section{Perfil e Concept da Anna}

A aranha nascida no Alabama, Anna, é a mais velha do grupo e a que muitas vezes faz papel da voz da razão. Tendo fugido de sua cidade natal por causa de conflitos políticos enquanto ainda era muito jovem, Anna busca em sua vida adulta manter a paz nos ambientes em que convive.

Tem uma carreira extensa em Faux City como parteira e curandeira, tendo realizado ou participado do parto de diversas crianças da cidade. Ironicamente, Anna nunca conseguiu ter filhos próprios, sofrendo diversos abortos espontâneos que levaram seu marido a abandonar o casamento. Adotou uma órfã, Jane, quando esta perdeu a mãe aos 10 anos de idade, e através dela conheceu a resistência feminina da cidade, vindo a se tornar no futuro uma das líderes mais influentes e poderosas do grupo. 
Anna é uma aranha de pele branca, olhos amarelos e cabelos compridos. Não é muito vaidosa e também não desafia padrões no que diz respeito ao seu vestuário e aparência. Abaixo, a exemplificação de sua personalidade no gráfico da zona de conforto:

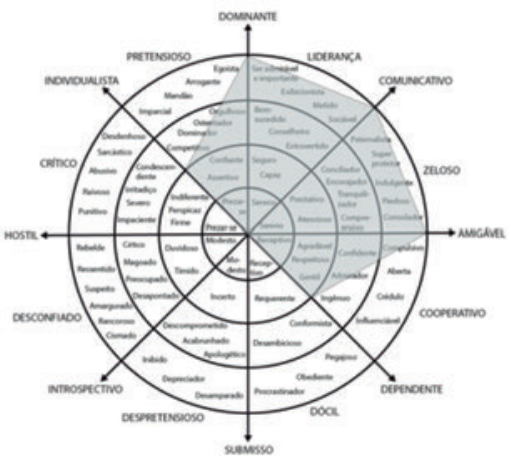

Gráfico 4 - Zona de conforto de Anna. Fonte: Hemilly Monteiro e Maielle Ramos (2018)

Considerando que seu background histórico envolve guerra e sua posição firme como uma mulher trabalhadora da classe operária, o perfil de Anna se assemelha muito à Real Woman do século XIX, criando um paralelo com as mulheres que assumiram a força de trabalho devido à baixa masculina causada pela Guerra Civil e deram início aos sussurros de independência financeira e direitos igualitários.

O primeiro passo para criá-la esteticamente foi estudar e testar a anatomia das aranhas. Diferentemente dos ratos, que compartilham a mesma classe - mamíferos - e número de membros, as aranhas possuem 8 olhos e 8 membros, resultando em uma anatomia mais desafiante que a estudada anteriormente.

Como no estudo dos ratos o resultado mais agradável se deu através da aproximação da anatomia craniana com a humana. Logo, buscou-se também estabelecer simetria com o posicionamento dos olhos no rosto. Porém, diferentemente dos ratos, percebeu-se que esse tipo de disposição gerava um rosto pouco expressivo e que por vezes causava associação com outros seres (como alienígenas e outros insetos) em vez de aranhas. Além disso, as duas primeiras alternativas, mostradas na figura que segue, apresentavam uma tendência a linhas retas ou curvas, faltando equilíbrio. A alternativa escolhida foi a terceira, que além de promover o equilíbrio mencionado, gerou uma associação mais direta ao "inseto aranha", e encaixou-se melhor com o corpo.

\section{GNATOMIA - GRANHAS}
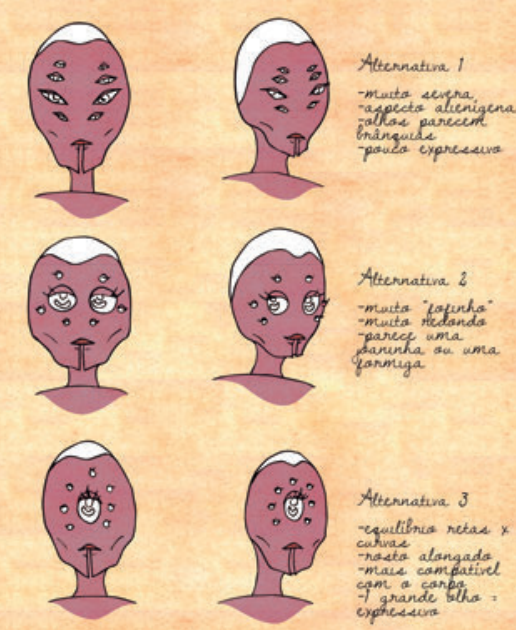

Alternativa 2 -munta "osurha. - parrec uma

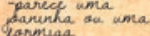
fanmiga

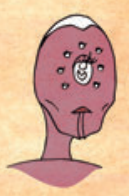

Aternativa 3 equalibre retas $x$ chosta alangada - mase compativel con a cancitho. expressura

Figura 27 - Estudo de anatomia craniana para aranhas do universo The Rotfather. Fonte: as autoras.

Os membros excedentes das aranhas demandaram um estudo de posicionamento em uma anatomia antropomorfizada. Colocou-se o segundo par de braços na região da costela abaixo do peito, por ser uma área que promove espaço em relação ao primeiro par e não interfere com a mobilidade da cintura. As pernas foram posicionadas de forma que um par fique virado para frente e um par para trás, criando uma semelhança com a anatomia humana quando observada pela vista frontal. As pernas das aranhas possuem vários segmentos, por isso a disposição dos pés foram feitas de uma maneira que simulasse uma pequena aranha da vida real na parte dos "dedos". Também pensando na divisão de segmentos, os dedos das mãos ganharam juntas mais acentuadas que os dedos dos ratos, dando a impressão de uma mão fina e ossuda. Considerando que as patas de aranhas na vida real vão afinando à medida que se aproximam da ponta, na anatomia estudada fez-se os dedos pontiagudos como agulhas - tanto os das mãos quanto os dos pés. Percebeu-se que a estrutura geral do corpo das aranhas assemelhava-se a uma pirâmide, com as patas servindo como base quadrangular. Por esse motivo, a $3^{a}$. alternativa de anatomia craniana da imagem que segue se adequa melhor ao corpo, com o grande olho expressivo fazendo o papel de topo da pirâmide. 


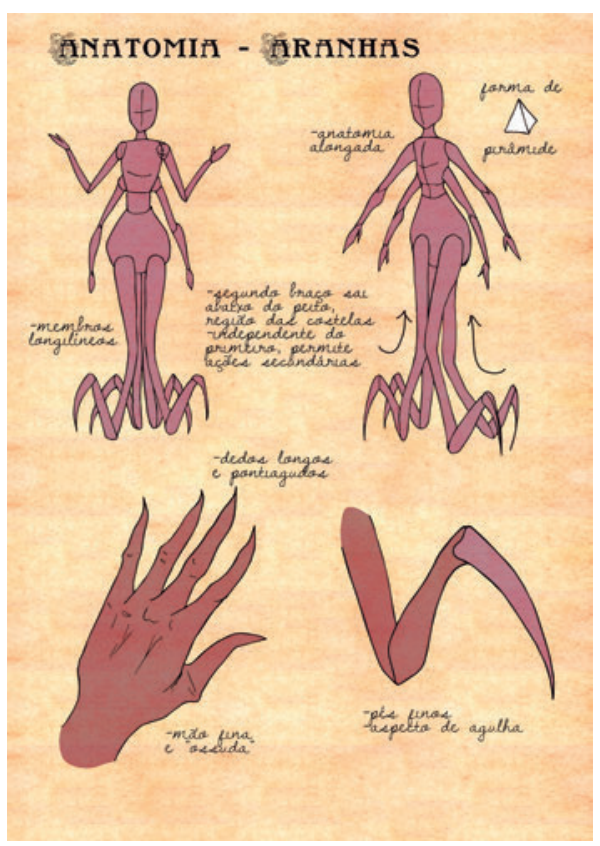

Figura 28 - Estudo de anatomia corporal de aranhas do universo The Rotfather Fonte: as autoras.

Estabelecida a anatomia, pôde-se virar o foco para a criação dos concepts finais de Anna com a montagem dos painéis semânticos:

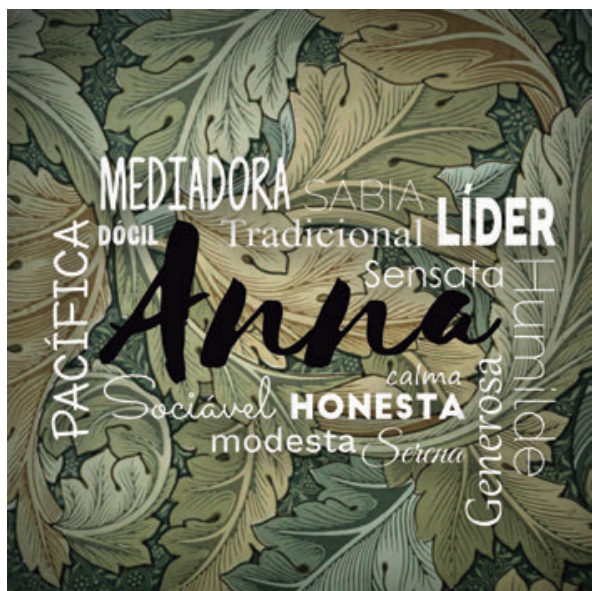

Figura 29 - Painel semântico de palavras da Anna. Fonte: as autoras.

Para acompanhá-lo, foi feito também o painel semântico visual com personas associadas ao perfil de Anna.

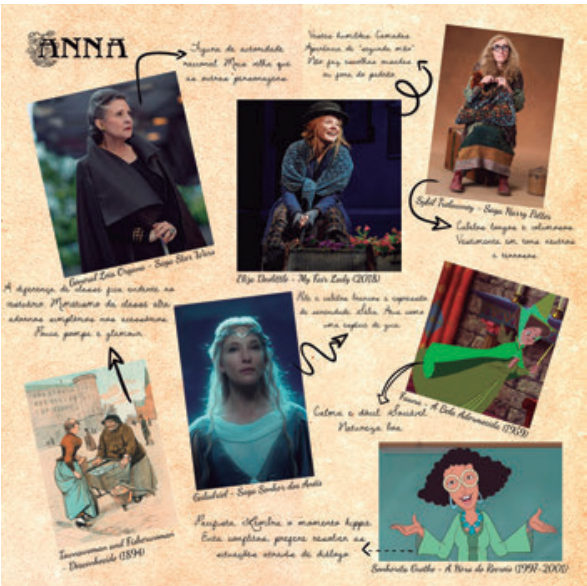

Figura 30 - Painel semântico de imagens da Anna. Fonte: as autoras.

No quesito psicológico, aponta-se as personagens General Leia Organa da saga de filmes Star Wars e Galadriel da saga Senhor dos Anéis como influências para a criação de uma figura de autoridade racional que atua como uma espécie de guia para as personagens mais jovens, muitas vezes repreendendo suas ações impulsivas. Também uma figura de autoridade, a professora Grotke da animação A Hora do Recreio (1997-2001) serviu de inspiração em relação ao estado de espírito da personagem, que é uma pacifista cuja personalidade se assemelha muito ao movimento hippie, bem como a fada Fauna da animação A Bela Adormecida (1959) por sua natureza calma e sociável. No que diz respeito ao figurino, a figura Townswoman and Fisherwoman (autor desconhecido, 1894) e a personagem Eliza Doolittle do musical My Fair Lady providenciaram as maiores referências para as peças de roupa e composição de looks, enquanto a professora Trelawney (saga Harry Potter) serviu de inspiração para as escolhas cromáticas gravitando mais em tons neutros e terrosos.

Em relação ao penteado, estabeleceu-se que Anna teria longos cabelos brancos, deixando bastante margem de interpretação para a maneira como ela os mantém. A primeira tentativa criada mostra um coque - penteado típico da época. Essa alternativa foi rejeitada por dar à personagem um ar de matrona, não combinando com a personalidade. A segunda alternativa foi uma tentativa de fazer alusão ao movimento hippie, com a faixa no cabelo e mechas volumosas. Apesar de interessante, o visual em geral ficou muito moderno e fez a personagem parecer muito mais nova, além do volume dar a ele uma característica dinâmica que colide com a personalidade serena de Anna. 


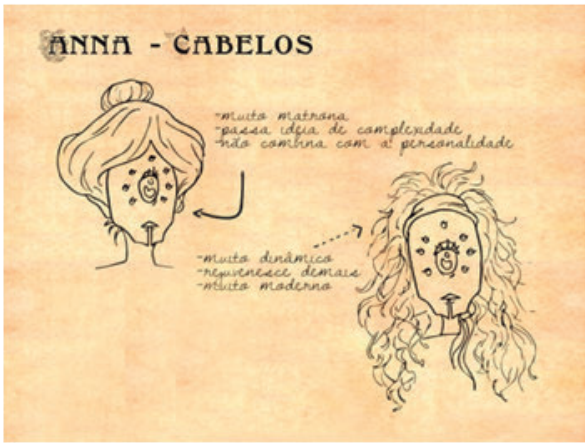

Figura 31 - Estudo de penteados de Anna - Alternativas 1 e 2. Fonte: as autoras.

A terceira alternativa, com as mechas longas e lisas, foi rejeitada por refletirem muita seriedade e pouca vida, o oposto do perfil da personagem. Por fim, a alternativa final de cabelos levemente ondulados foi escolhida por ter uma silhueta de equilíbrio entre ordem e leveza, e apresentar movimento com as mechas esvoaçantes e um ar de simplicidade, como se a personagem tivesse prendido os cabelos sem preocupação e esforço. Variações desse modelo permitem cabelo totamente solto e tranças com fios puxados, como se tivessem sido feitas com pressa.

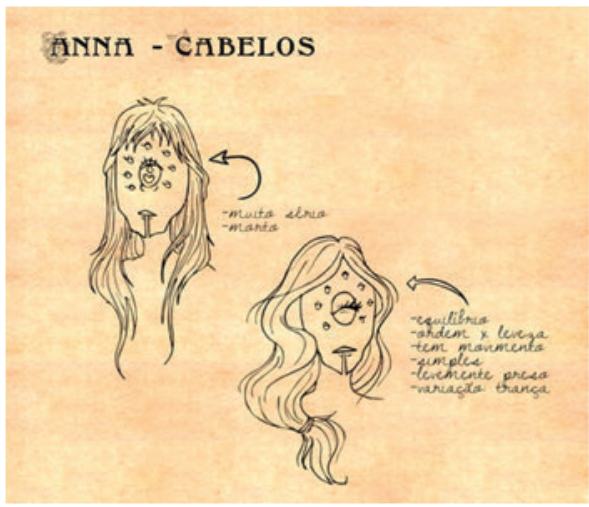

Figura 32 - Estudo de penteados de Anna - Alternativas 3 e 4 . Fonte: as autoras.

Sendo Anna a personagem de classe mais baixa entre as três, a diferença social fica clara quando analisada a maneira como se veste. Não sendo particularmente vaidosa, Anna é o tipo de mulher que vestiria o que tem sem se preocupar em fazer uma declaração de moda. Observa-se um mimetismo da classe baixa em relação à classe rica quando compara-se os acessório de Anna com os de Rita: enquanto Rita usa plumas, fitas e rosas em seus chapéus, Anna apresenta equivalentes mais simples como ramos de palha e florzinhas do mato; enquanto Rita usa capas de pelos, Anna se aquece com xales de crochê. Em referência à sua profissão de parteira e sua posição como membro da classe trabalhadora, Anna usa sempre um avental ou pano amarrado na cintura. A aparência gasta e sobreposição de várias peças sugerem roupas usadas por muitos anos que talvez não sejam mais tão eficientes em mantê-la aquecida. Anna mantém as mesmas roupas de anos atrás não por não ter como adquirir roupas novas, mas por não ter vaidade ou ver necessidade de substituí-las se ainda estão boas.

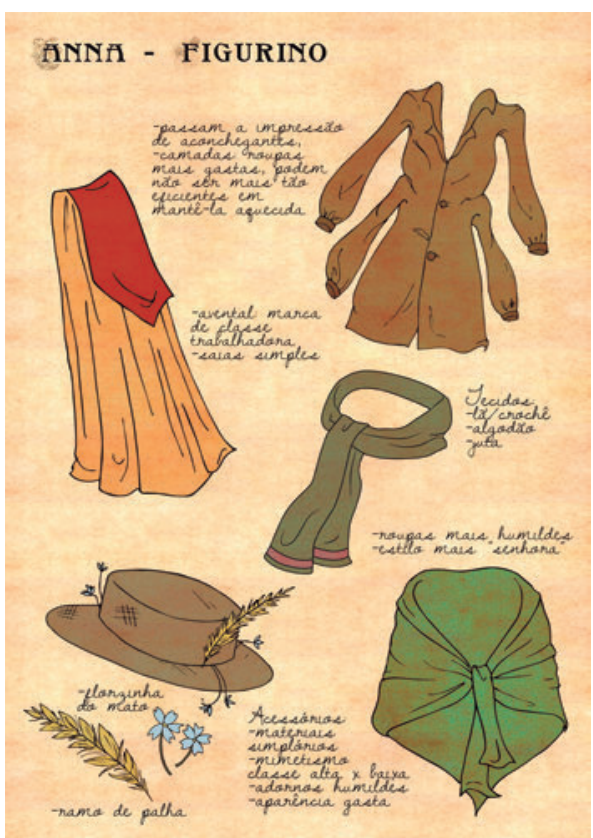

Figura 33 - Estudo de figurino de Anna. Fonte: as autoras.

O painel de elementos abaixo apresenta a paleta cromática do vestuário de Anna, ou seja, marrons, verdes e tons terrosos em geral. As texturas representam os tecidos que costuma vestir. No sentido de cima para baixo e da esquerda para a direita, são eles: juta, lã/crochê, algodão, camurça e estampas xadrez. 


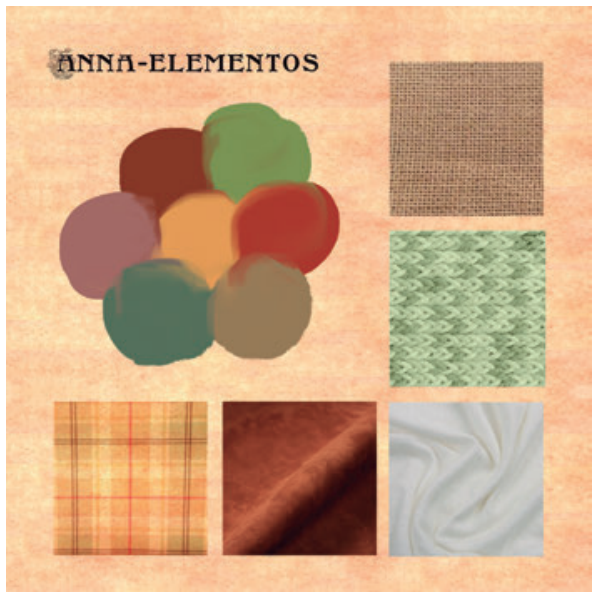

Figura 34 - Painel de paleta cromática e texturas da Anna

Sempre calma e serena, sua expressão padrão é feliz e agradável. Nos momentos de tristeza, tende a se retrair para refletir sobre o que passou, demonstrando calma até em momentos devastadores. Em seus raros episódios de raiva e perda de controle, a expressão serena de seus olhos muda para agressividade, e seus cabelos se espalham, simulando as mechas de cobra da personagem Medusa que dá nome ao grupo.

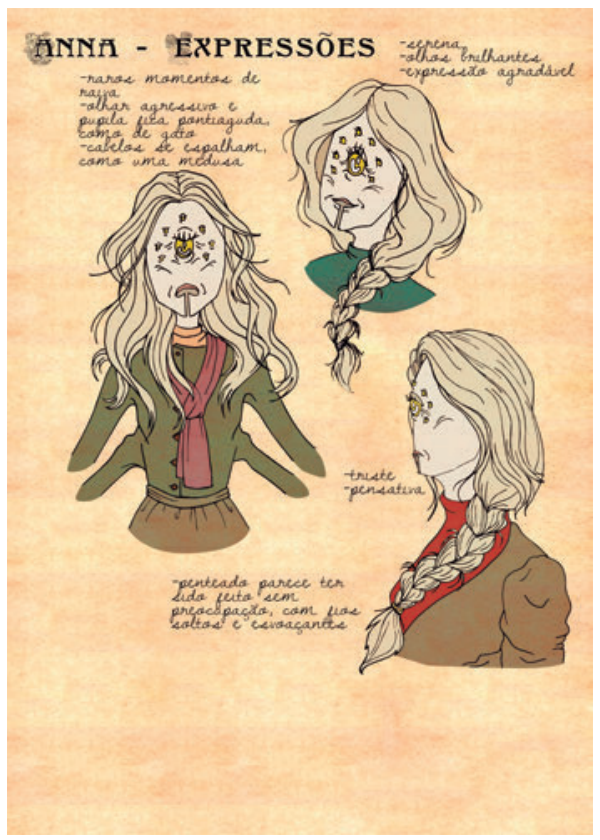

Figura 35 - Estudo de expressões de Anna. Fonte: a autora.
Os elementos definidos podem ser vistos em aplicação nos concepts finais mostrados a seguir, conferindo a etapa "Entregar" do método Double Diamond, em referência à personagem Anna.

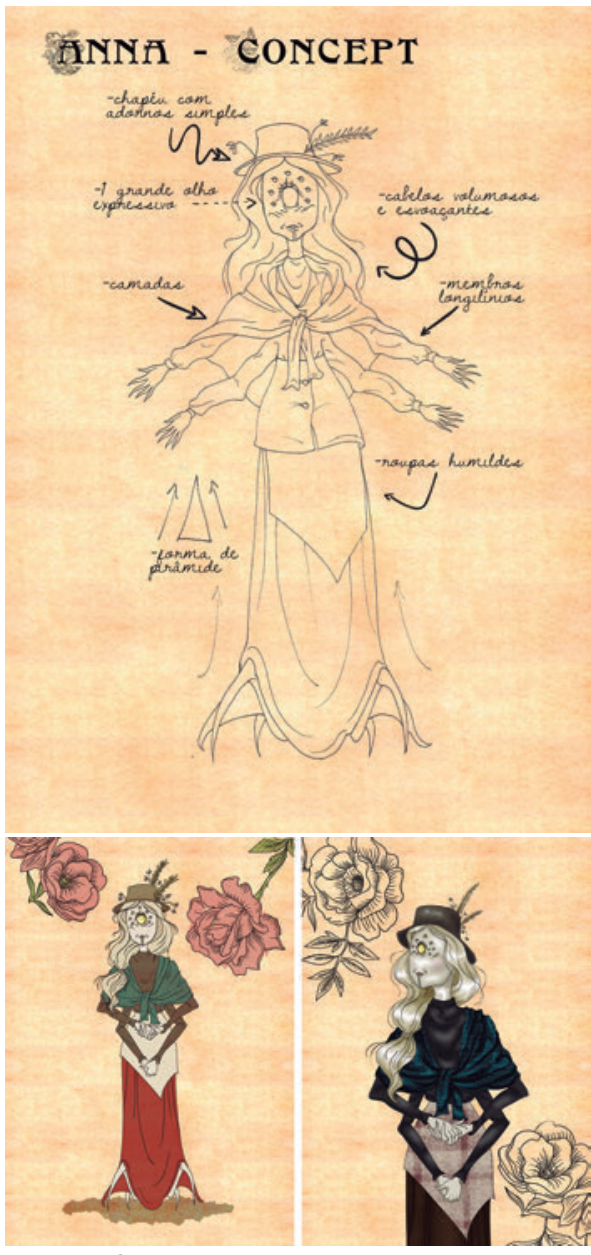

Figura 36 - Concept de corpo todo da personagem Anna. Fonte: a autora.

\section{Conclusão}

Apesar do engajamento do público com personagens ser um dos fatores mais fortes para o sucesso de uma narrativa, em especial em universos de franquias, transmídia, os perfis femininos ao longo da história das mídias de entretenimento foram, em sua grande maioria, consistentemente negligenciados, estereotipados, sexualizados e resumidos a característica superficiais (Rosa, 2018; Fontão 2019).

À medida que o tempo passa e a sociedade avança, a mulher tem buscado, e alcançado gradualmente, 
seu espaço de representação e na indústria do entretenimento não é diferente.

Com mulheres ocupando cada vez mais espaços em universidades, cargos políticos e buscando independência, percebe-se que o público feminino, em todas as esferas da sociedade, luta e clama para ser visto como pessoas que merecem igualdade de direitos e oportunidades. É natural, portanto, que se queira ver melhores representações em personagens fictícias também, com o público feminino estando saturado de se ver representado como instrumentos de desejo com personalidades rasas, existências dependentes e resumidas a entreter a vida de homens e, muitas vezes, tratadas como objetos intercambiáveis ou substituíveis.

Com esse conceito em mente, este trabalho é um passo na direção de, na pesquisa teórico-prática aplicada o contexto do projeto The Rotfather, servir de exemplo de criação condizentes aos anseios do público feminino, demonstrando não apenas um processo criativo que possa ser replicado por outros, mas também uma influência positiva como veículo de voz e espaço a criadoras mulheres, para que estas possam mudar para melhor a representação feminina nas mídias, além de moldar a indústria do entretenimento em um lugar acolhedor onde pessoas de todas as origens, gêneros e sexualidades possam se sentir bem representados como os seres humanos complexos que são.

\section{Referências Bibliograficas}

American Experience. 2018. Documentário American Experience. Chapter 1: The Gilded Age. PBS. https://www. youtube.com/watch?v=AeWE_FalP6k>. Acesso em 4 de novembro de 2019.

Calhoun, Charles W. 2007. The Gilded Age. Perspectives on the Origins of Modern America. Rowman \& Littlefield.

Cruea, Susan M. 2005. Changing Ideals of Womanhood During the Nineteenth-Century Woman Movement. General Studies Writing Faculty Publications. 1.

Design Council. Double Diamond Process. https:// www.designcouncil.org.uk/news-opinion/what-frameworkinnovation-design-councils-evolved-double-diamond. Acesso em 4 de novembro de 2019.

Fontão, Isabel. C. 2019. Concept de personagens femininos para a história em quadrinhos "Medusas" do universo transmídia The Rotfather. Projeto de Conclusão de Curso, Curso de Design da Universidade Federal de Santa Catarina. Florianópolis, SC, Brasil.

Howard, Jeremy. 1996. Art Nouveau: International and National Styles in Europe. Manchester University Press.

Jenkins, Henry. 2003. Transmedia Storytelling - Moving characters from books to films to videogames can make them stronger and more compelling. In: Technology Review. MIT.https://www.technologyreview.com/s/401760/ transmedia-storytelling/. Acesso em 4 de novembro de 2019.

Jenkins, Henry. 2007. Transmedia Storytelling 101. http://henryjenkins.org/blog/2007/03/transmedia storytelling_101.html. Acesso em: 4 de novembro de 2019.

Lessa, Antônio Carlos. 2005. História das Relações Internacionais - A Pax Britannica e o mundo do século XIX.
1. Ed. Petrópolis: Vozes. v. 1. 168p.

Nascimento, Hemilly Monteiro Gaudêncio do. 2018. Adaptação do Feminino em Universo Transmídia Um Case da Franquia The Rotfather. JIG - Jornada Internacional Geminis.

Rosa, Heloisa Cardoso da. Criação e Reestruturação de Personagens para o Universo Transmídia The Rotfather. 2018. Projeto de Conclusão de Curso, Curso de Design da Universidade Federal de Santa Catarina. Florianópolis, SC, Brasil.

Rosa, Heloisa. Andrade, Wiliam M. De.. 2018. Representação feminina e a Lenda de Korra: quebra de padrões de gênero por meio da protagonista. Intercom - Sociedade Brasileira de Estudos Interdisciplinares da Comunicação. XIX Congresso de Ciências da Comunicação na Região Sul - Cascavel - PR

Schell, Jesse. 2008. The Art of Game Design: A Book of Lenses. Burlington: Morgan Kaufmann Publishers.

Sears, Roebuck and Company. 1898. Consumers Guide no. 107. https://archive.org/details/ consumersguideno00sear/pag e / n2. Acesso em 4 de novembro de 2019.

Stein, Mônica. 2015. O Uso da Estratégia Transmídia e de Licenciamento para o Jogo "The Rotfather": Uma Ótica Mercadológica para movimentar demais Indústrias Criativas. In: SBGAMES, 14., 2015, Teresina. Proceedings... . Teresina: Sbgames, p. 1151 - 1160.

Welter, Barbara. 1976. Dimity Convictions: The American Woman in the Nineteenth Century. Athens: Ohio UP.

Welter, Barbara. 1966. The Cult of True Womanhood: 1820-1860. American Quarterly, Vol. 18, No. 2, Part 1 (Summer, 1966), pp. 151-174. 